JURNAL KEBIDANAN

Vol 6, No 2, April 2020 : 148-154

\title{
DURASI PEMBERIAN ASI EKSKLUSIF TERHADAP MORDIBITAS BAYI DALAM SATU TAHUN PERTAMA KEHIDUPAN DI WILAYAH KERJA PUSKESMAS SAWAN I
}

\author{
Putu Dian Prima Kusuma Dewi ${ }^{1}$, Lina Anggaraeni Dwijayanti ${ }^{2}$, Luh Ayu Purnami ${ }^{3}$, Ari Pertama \\ Watiningsih ${ }^{4}$, Kadek Nadia Sintia Dewi ${ }^{5}$
1Dosen Kebidanan Sekolah Tinggi Ilmu Kesehatan Buleleng
Email : dian_pkd@yahoo.co.id
2Dosen Kebidanan Sekolah Tinggi IImu Kesehatan Buleleng
Email : linaanggaraeni@gmail.com
3Dosen Kebidanan Sekolah Tinggi Ilmu Kesehatan Buleleng
Email : ayupurnami@gmail.com
4Dosen Kebidanan Sekolah Tinggi Ilmu Kesehatan Buleleng
Email : arivito@yahoo.com
5Mahasiswa S1-Kebidanan
Email : sintiadewi@gmail.com

\begin{abstract}
Background Exclusive breastfeeding which does not optimally increase the risk of death in infants. Indonesia has coverage of breastfeeding which is still far from the global target. mordibity.

Purpose this research to analyze the effect of the duration of exclusive breastfeeding on infant

Methods longitudinal analytic study with a retrospective cohort approach and crossectional retrieval. The analysis used was cox regression using SPSS version 17. Samples were 189 people using the interview method.

Result the incidence of infant morbidity rate with duration of breastfeeding less than six months was 46 per 100 Person Years with median time of morbidity at 1.63 months. It was proven that the duration of breastfeeding for less than six months affected the baby's mordibity up to 14.6 times (9.28-22.97 p 0.01). Mothers with working status 1.5 times (1.13-2.12 $p$ 0.01) and working time more than six hours 1.5 times (1.03-2.26 $p$ 0.03) affect the baby's mordibity in the first year of life. The duration of breastfeeding is less than six months, the status of the mother working and the length of work more than six hours has an effect on the level of mordibitas in the baby.

Conclusion The duration of exclusive breastfeeding affects the level of mordibity in infants. The duration of breastfeeding less than six months has been proven to be 14.6 times increasing mordibity in infants compared to breastfeeding for more than six months. In addition, the social characteristics of mothers who work more than six hours a day 1.5 times increase mordibity in their babies.

Sugesstion Counseling for women workers who are breastfeeding must be realized by providing space and facilities that can support exclusive breastfeeding so as to reduce the incidence of mordibity in infants. Information about breast milk and how to store breast milk also needs to be well socialized.
\end{abstract}

Keywords: Duration, eksklusif, mordibity

\section{ABSTRAK}

Latar Belakang Pemberian ASI Eksklusif yang tidak optimal meningkatkan risiko kematian pada bayi. Indonesia memiliki cakupan pemberian ASI yang masih jauh dari target global.

Tujuan untuk menganalisis pengaruh durasi pemberian ASI Eksklusif terhadap mordibitas bayi.

Metode Penelitian longitudinal analitik dengan pendekatan secara kohort retrospektif dan pengambilan secara crossectional. Analisis yang digunakan adalah cox regresi menggunakan SPSS versi 17. Sampel berjumlah 189 orang menggunakan metode wawancara.

Hasil Insiden rate mordibitas bayi dengan durasi pemberian ASI kurang dari enam bulan sebesar 46 per 100 PY (person years) dengan median time mordibitas pada 1.63 bulan. Terbukti durasi pemberian ASI kurang dari enam bulan berisiko terhadap mordibitas bayi hingga 14.6 kali (9.28-22.97 $p$ 0.01). Ibu dengan status bekerja 1.5 kali $(1.13-2.12 p$ 0.01) dan lama bekerja lebih dari enam jam 1.5 kali (1.03-2.26 $p$ 0.03) berisiko terhadap 
mordibitas bayi dalam satu tahun kehidupan pertama. Durasi pemberian ASI kurang dari enam bulan, status ibu bekerja dan lama bekerja lebih dari enam jam berisiko terhadap tingkat mordibitas pada bayi.

Kesimpulan Durasi pemberian ASI Eksklusif berpengaruh terhadap tingkat mordibitas pada bayi. Durasi pemberian ASI kurang dari enam bulan terbukti 14.6 kali meningkatkan mordibitas pada bayi dibandingkan pemberian ASI lebih dari enam bulan. Selain itu karakteristik sosial yaitu dengan ibu yang bekerja lebih dari enam jam sehari 1.5 kali meningkatkan mordibitas pada bayinya.

Saran Konseling terhadap pekerja wanita yang menyusui harus direalisasikan dengan memberikan ruang dan fasilitas yang dapat mendukung pemberian ASI Eksklusif sehingga dapat menurunkan kejadian mordibitas pada bayi. Informasi mengenai ASI perah dan cara menyimpan ASI juga perlu disosialisasikan dengan baik.

Kata Kunci : Durasi, eksklusif, mordibitas

\section{PENDAHULUAN}

Pemberian ASI Eksklusif yang tidak optimal meningkatkan risiko kematian pada bayi. Secara global pemberian ASI secara eksklusif dan berkelanjutan sampai usia 2 tahun masih rendah hanya mencapai $38 \%$. Pemberian ASI yang tidak optimal tersebut memberikan kontribusi pada 800.000 kematian bayi (WHO, 2012, 2016). WHO memiliki target program ASI untuk cakupan pemberian ASI pada 6 bulan pertama hingga minimal 50\% sampai tahun 2025 (WHO, 2012). Banyak negara berkembang memiliki cakupan pemberian ASI yang rendah termasuk Indonesia dengan cakupan ASI eksklusif sebesar 30,4\% dengan keberlanjutan pemberian ASI sampai umur 2 tahun hanya 50,4\% (Global, Bank, Feeding, Children, \& Children, 2007).

Bali merupakan provinsi dengan cakupan pemberian ASI yang tinggi namun juga termasuk provinsi dengan pemberian susu formula tertinggi di Indonesia yaitu 93,7\% (RI, 2014). Cakupan pemberian ASI eksklusif di Kabupetan Buleleng Bali dilaporkan menurun dari $70,6 \%$ pada tahun 2014 menjadi 62\% pada tahun 2015 (Buleleng, 2014; Dinas Kesehatan Kabupaten Buleleng, 2015; RI, 2014). Puskesmas di Kabupaten Buleleng yang memiliki cakupan pemberian ASI Eksklusif menurun yaitu Puskesmas Sawan I yaitu dari $77 \%$ di tahun 2015 menjadi $74,82 \%$ di tahun 2016 (Yuliasih, 2016).

Pemberian ASI pada bayi baru lahir secara eksklusif selama 6 bulan dan diteruskan hingga 2 tahun menjadi jaminan keberlangsungan 1000 hari kehidupan pertama pada bayi. Penanganan masalah pemberian ASI seringkali terabaikan padahal ASI merupakan nutrisi utama yang diperlukan oleh bayi. Melihat pentingnya pemberian ASI, banyak upaya yang telah dilakukan seperti kampanye ASI dan pelatihan konselor menyusui namun aplikasi di masyarakat belum optimal termasuk kegiatan promosi susu formula yang justru muncul dari tenaga kesehatan. Persentase menyusui eksklusif menurun seiring dengan peningkatan umur bayi hingga $33 \%$ pada umur diatas 6 bulan (Lee \& Jang, 2016; RI, 2014; Takahashi, Ganchimeg, Ota, \& Vogel, 2017). Median time keberlangsungan pemberian ASI eksklusif yaitu antara 3-10,9 minggu (Babakazo et al., 2015; Global et al., 2007). Median time ini menunjukkan bahwa masih banyak bayi yang tidak mendapatkan ASI secara eksklusif sampai batas waktu yang dianjurkan. Pemberian ASI secara eksklusif mampu meningkatkan bounding antara ibu dan bayi, meningkatkan daya tahan tubuh bayi dan merangsang perkembangan emosi dan kecerdasan bayi(Haghighi \& Abbasi, 2015; RI, 2014; WHO, 2012, 2016).

Kelangsungan pemberian ASI sangat menentukan pertumbuhan dan perkembangan bayi selanjutnya. Walaupun banyak susu formula yang diproduksi dengan kandungan menyerupai ASI namun antibodi dan immunoglobulin merupakan zat penting yang tidak akan bayi peroleh dari nutrisi eksternal (Fraser, 2011). Bayi yang mendapat ASI sejak lahir dan eksklusif terbukti memiliki daya tahan tubuh yang lebih baik, dikaitkan dengan risiko infeksi saluran cerna yang lebih rendah di tahun pertama kehidupan dan memiliki perkembangan kognitif yang lebih baik dibandingkan dengan bayi yang tidak mendapatkan ASI (Kemenkes, 2013; Made Kurnia Widiastuti Giri, Nunuk Suryani, 2013).

Beberapa penelitian menunjukkan bahwa pemberian ASI Eksklusif berpengaruh pada mordibitas seperti kejadian diare, infeksi pernafasan akut (ISPA) dan konstipasi. Kejadian diare pada bayi yang diberikan ASI Eksklusif lebih rendah dibandingkan bayi yang mendapatkan susu formula. Faktor risiko kegagalan pemberian ASI yaitu ibu primigravida, pendidikan yang rendah, kurangnya konseling terkait ASI saat melahirkan, kehamilan, dan post partum, keyakinan yang keliru tentang makanan bayi, promosi susu formula, masalah 
kesehatan pada ibu dan bayi, kurangnya dukungan tenaga kesehatan dan peran tenaga kesehatan yang rendah dalam menunjang keberhasilan ASI Eksklusif (Afifah et al., 2007; Asmarani Dian Pratiwi et al., 2018; Babakazo et al., 2015; Emma et al., 2014; Fatmawati et al., 2010; Lee \& Jang, 2016; Putu Dian Prima Kusuma Dewi et al., 2016; Saleh, 2011; Suresh et al., 2014; Takahashi et al., 2017; Tilahun et al., 2016; WHO, 2016)

Banyak penelitian yang menunjukkan faktor resiko kegagalan pemberian ASI eksklusif namun belum ada penelitian yang menjelaskan pengaruh durasi pemberian ASI eksklusif terhadap tingkat mordibitas atau kesakitan bayi dalam satu tahun kehidupan pertama khususnya di Kabupaten Buleleng dan Indonesia pada umumnya. Hasil penelitian ini dapat menjadi indikator waktu pemberian konseling menyusui yang lebih intensif sebagai bentuk antisipasi kesakitan pada bayi di 1000 hari kehidupan pertama. Sekaligus menjadi bahan masukan untuk monitoring dan evaluasi keberhasilan pemberian ASI eksklusif. Makadari itu penelitan ini bertujuan untuk menganalisis pengaruh durasi pemberian ASI Eksklusif terhadap mordibitas bayi.

\section{METODE PENELITIAN}

Penelitian ini merupakan penelitian longitudinal analitik dengan pendekatan secara retrospektif dan pengambilan secara crossectional. Penelitian ini menggunakan data primer dari ibu yang memiliki bayi umur $0-12$ bulan dengan jumlah sampel 189 orang. Penelitian ini dilaksanakan di Wilayah Kerja Puskesmas Sawan I periode waktu Mei - Juni 2018. Variabel yang identifiksi dalam penelitian ini meliputi durasi pemberian ASI,pendidikan ibu, pekerjaan ibu,lama bekerja,usia ibu,jumlah anak,jarak anak,jumlah kunjungan ANC,jenis persalinan, pemberian kolostrum dan riwayat Inisiasi Menyusu Dini (IMD).

Instrument penelitian yang digunakan adalah lembar wawancara. Data dianalisis menggunakan analisis multivariat cox regresi menggunakan metode backward, eksistensi variabel confounding ditetapkan dengan signifikansi $5 \%$ dan perubahan survival/hazard rate $10 \%$ atau lebih pada variabel utama dengan program software SPSS 18. Analisis multivariabel dilakukan untuk mendapatkan model yang bisa menerangkan pengaruh durasi pemberian ASI Eksklusif terhadap mordibitas bayi.

\section{HASIL DAN PEMBAHASAN}

Hasil penelitian menunjukkan bahwa insiden rate mordibitas pada bayi yang tidak diberikan ASI secara Eksklusif sebesar 46 per 100 person years sedangkan pada bayi dengan ASI eksklusif sebesar 17 per 100 person years. Angka ini menunjukkan bahwa bayi yang diberikan ASI dengan durasi yang lebih lama ( $>6$ bulan) memiliki tingkat kesakitan pada bayi yang lebih rendah dibandingkan bayi yang mendapatkan ASI kurang dari enam bulan. Hal ini membuktikan bahwa pemberian ASI secara eksklusif sangat penting dan berguna untuk meningkatkan daya tahan tubuh bayi. ASI mengandung immunoglobulin (lg) yang sangat diperlukan oleh bayi dalam 1000 hari kehidupan pertamanya. Ig ini tidak akan didapatkan dari konsumsi makanan ataupun susu formula (Fracer, 2011). Berikut merupakan sajian bentuk kurva terkait tingkat mordibitas pada bayi berdasarkan durasi pemberian ASI.

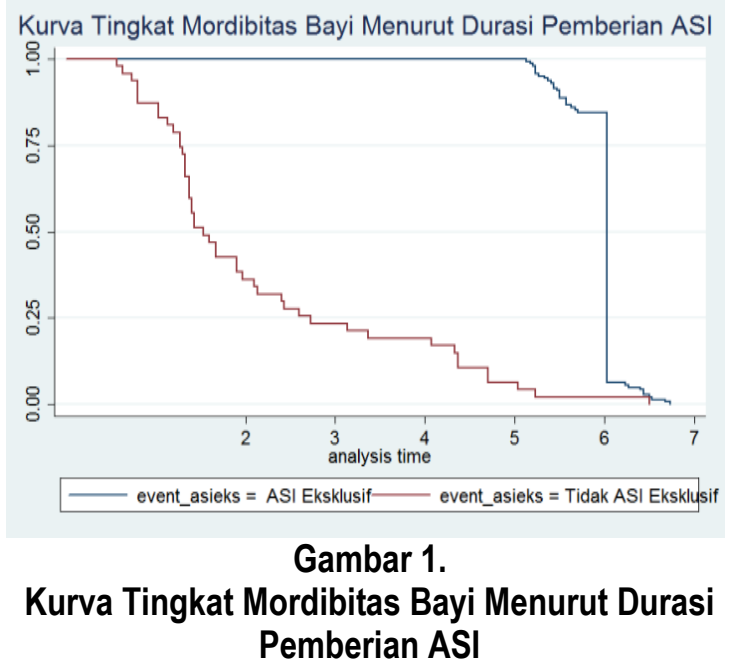

Grafik diatas menunjukkan bahwa tingkat mordibitas pada bayi semakin meningkat pada bayi yang tidak mendapatkan ASI secara eksklusif. Median time kejadian atau $50 \%$ bayi yang tidak mendapatkan ASI secara eksklusif mengalami kesakitan pada 1.63 bulan kehidupan pertama. Sedangkan median time mordibitas bayi yang mendapatkan ASI eksklusif pada 6.03 bulan. Artinya ketika bayi tidak mendapatkan ASI secara eksklusif maka kejadian kesakitan atau mordibitas terjadi lebih dini.

Berdasarkan tabel 1 menunjukkan bahwa pendidikan ibu ( $p 0.01)$, lama bekerja dalam rentang waktu 6 jam (p 0.01) dan riwayat IMD (p 0.03). Namun hasil perbedaan proporsi ini perlu di analisis lebih lanjut secara multivariat. secara statistic untuk kasus mordibitas pada bayi berdasarkan durasi pemberian ASI ( $p$ 0.01), pada terdapat perbedaan proporsi yang bermakna. 
Tabel 1.

Mordibitas Bayi Dalam Satu Tahun Pertama Kehidupan Menurut Karakteristik Sosial, Demografi dan Gestasi

\begin{tabular}{|c|c|c|c|c|}
\hline \multirow[t]{2}{*}{ Karakteristik } & \multicolumn{2}{|c|}{ Responden } & \multicolumn{2}{|c|}{ Mordibitas } \\
\hline & $\mathrm{n}$ & $\%$ & $\mathrm{n}$ & Nilai $p$ \\
\hline 1 & 2 & 3 & 4 & 5 \\
\hline Durasi Pemberian ASI & & & & $0.01^{*}$ \\
\hline$\geq 6$ bulan & 142 & 75.13 & 100 & \\
\hline$<6$ bulan & 47 & 24.87 & 0 & \\
\hline Pendidikan Ibu & & & & $0.01^{*}$ \\
\hline Dasar (9 tahun) & 168 & 88.89 & 100 & \\
\hline Lanjut (> 9 tahun) & 21 & 11.11 & 0 & \\
\hline Pekerjaan Ibu & & & & 0.15 \\
\hline IRT/ tidak bekerja & 75 & 39.68 & 36.68 & \\
\hline Bekerja & 114 & 60.32 & 63.64 & \\
\hline Lama Bekerja & & & & $0.01^{*}$ \\
\hline$\leq 6$ jam & 153 & 80.95 & 90.91 & \\
\hline$>6$ jam & 36 & 19.05 & 9.09 & \\
\hline Usia Ibu & & & & 0.79 \\
\hline Usia sehat & 143 & 75.66 & 81.82 & \\
\hline Usia tidak sehat & 46 & 24.34 & 18.18 & \\
\hline Jumlah anak & & & & 0.80 \\
\hline 1-2 orang & 134 & 70.90 & 36.36 & \\
\hline$>2$ orang & 55 & 29.10 & 63.64 & \\
\hline Jarak anak & & & & 0.47 \\
\hline$>2$ tahun & 112 & 59.26 & 72.73 & \\
\hline$\leq 2$ tahun & 77 & 40.74 & 27.27 & \\
\hline Jumlah kunjungan ANC & & & & 0.67 \\
\hline $\begin{array}{l}\geq 4 \text { kali } \\
>4 \text { kali }\end{array}$ & 182 & 96.30 & 100 & \\
\hline $\begin{array}{l}>4 \text { kali } \\
\text { Jenis Persalinan }\end{array}$ & 7 & 3.70 & 0 & 012 \\
\hline Normal (per vaginam) & 168 & 88.89 & 90.91 & \\
\hline Sectio Caesarea (SC) & 21 & 11.11 & 9.09 & \\
\hline Pemberian Kolostrum & & & & 0.17 \\
\hline Diberikan semua & 178 & 94.18 & 3.37 & \\
\hline Dibuang & 11 & 5.82 & 45.45 & \\
\hline Riwayat Inisiasi Menyusu Dini (IMD) & & & & $0.03^{*}$ \\
\hline Dilakukan & 129 & 68.25 & 81.82 & \\
\hline Tidak dilakukan & 60 & 31.75 & 18.8 & \\
\hline
\end{tabular}

Tabel 2.

Multivariat Pengaruh Durasi Pemberian ASI terhadap Mordibitas Bayi dalam Satu Tahun Kehidupan Pertama

\begin{tabular}{|c|c|c|}
\hline Karakteristik & Hazard Ratio (95 \% Cl) & $p$ \\
\hline 1 & 2 & 3 \\
\hline \multicolumn{3}{|l|}{ Durasi Pemberian ASI } \\
\hline $\begin{aligned} & \geq 6 \text { bulan } \\
< & 6 \text { bulan }\end{aligned}$ & $\begin{array}{c}1.00 \text { (ref) } \\
14.60(9.28-22.97)\end{array}$ & 0.01 \\
\hline \multicolumn{3}{|l|}{ Lama Bekerja } \\
\hline$\leq 6 \mathrm{jam}$ & 1.00 (ref) & \\
\hline \multicolumn{2}{|l|}{ Pekerjaan Ibu } & 0.03 \\
\hline IRT/ tidak bekerja & $1.00 \mathrm{ref})$ & \\
\hline Bekerja & $1.55(1.13-2.12)$ & 0.01 \\
\hline
\end{tabular}

$*$ p-value $<0,05$ untuk multivariat 
Analisis secara multivariat menunjukkan bahwa terdapat tiga variabel yang meningkatkan mordibitas pada bayi yaitu durasi pemberian ASI kurang dari enam bulan, lama bekerja lebih dari enam jam dan status ibu bekerja.

Durasi pemberian ASI berpengaruh terhadap kejadian mordibitas pada bayi dimana bayi dengan yang diberikan ASI kurang dari 6 bulan terbukti 14.6 kali (9.28-22.97 p 0.01) mengalami mordibitas dibandingkan bayi yang mendapatkan ASI lebih dari enam bulan. Pemberian ASI eksklusif selama 6 bulan atau lebih memberikan efek protektif yang lebih besar berkaitan dengan respon dosis efek protektif yang dihasilkan. Semakin besar dosis ASI yang diberikan semakin besar pula efek protektif yang dihasilkan. Hal ini dapat dijelaskan bahwa ASI sebagai proteksi pasif berpengaruh terhadap respon imun sistem anak dengan maturasional, anti inflamasi, imunomodulator, dan antimikrobial. Respon imun berkaitan dengan dosis ASI bekerja secara biologikal selama 4 bulan atau 6 bulan atau bahkan beberapa tahun. ASI dapat juga memberikan perlindungan jangka panjang melalui stimulasi respon imun aktif. Imunitasi aktif merupakan imunitas spesifik dimana sistem imun membentuk memori jangka panjang terhadap paparan antigen tertentu (Takahashi et al., 2017).

Ibu yang bekerja terbukti meningkatkan mordibitas pada bayi hingga 1.5 kali dibandingkan ibu yang tidak bekerja. Hal ini sejalan dengan tingkat kegagalan pemberian ASI dimana faktor status bekerja terbukti sebagai faktor risiko kegagalan pemberian ASI. Didapatkan ibu yang bekerja 4,1 kali lebih berisiko gagal dalam pemberian ASI Eksklusif dibandingkan pada ibu yang tidak bekerja. Pekerjaan ditemukan berpengaruh secara signifikan terhadap pemberian ASI Ekslusif (Arora et al., 2017; Suresh et al., 2014). Penelitian lain yang serupa mendapatkan bahwa ibu bekerja sebagai faktor risiko kegagalan pemberian ASI dengan AOR 4,549 (Nurmiati, 2008). Kondisi ibu yang bekerja akan mengurangi intensitas ibu untuk menyusui sehingga tentu akan mempengaruhi daya tahan tubuh bayi sehingga mudah untuk sakit.

Sejalan dengan kondisi ibu yang bekerja bahwa dalam penelitian ini menunjukkan ibu yang bekerja lebih dari enam jam sehari juga berpengaruh terhadap mordibitas bayi hingga 1.5 kali. Hasil ini konsisten dan sejalan dengan hasil penelitian yang menunjukkan ibu yang bekerja meningkatkan mordibitas pada bayi. Pada ibu yang menyusui, peran ganda sebagai ibu bekerja tentu sangat sulit untuk dijalani. Peraturan cuti yang hanya diberikan selama 3 bulan membuat banyak ibu harus menyiapkan makanan pendamping ASI sebelum masa cutinya habis, sehingga pemberian ASI menjadi tidak optimal (Gadhavi et al., 2013; Khasawneh \& Khasawneh, 2017; Shifraw, Worku, \& Berhane, 2015). Selain itu ibu memiliki pengetahuan kurang tentang ASI perah dan cara menyimpan ASI perah. Upaya pemerintah dalam menggalakkan pemberian ASI telah terlihat dengan adanya kebijakan dan strategi Departemen Kesehatan RI tentang Peningkatan Pemberian ASI (PP-ASI) pekerja wanita yaitu dengan mengupayakan fasilitas yang mendukung PP-ASI bagi ibu yang menyusui di tempat kerja dengan menyediakan sarana ruang memerah ASI, menyediakan perlengkapan untuk memerah dan menyimpan ASI menyediakan materi penyuluhan ASI, dan memberikan penyuluhan (Depkes RI, 2010). Ironisnya pada beberapa instansi tempat bekerja masih belum merealisasikan program pemerintah seperti yang telah tertuang.

Durasi pemberian ASI sangat mempengaruhi ketahanan hidup bayi di Indonesia. Bayi yang disusui dengan durasi 6 bulan atau lebih memiliki ketahanan hidup 33,3 kali lebih baik daripada bayi yang disusui kurang dari 4 bulan, dan bayi yang disusui dengan durasi 4-5 bulan memiliki ketahanan hidup 2,6 kali lebih baik daripada bayi yang disusui kurang dari 4 bulan (Nurmiati, 2008). ASI memiliki efek jangka panjang terhadap pertumbuhan dan perkembangan bayi, serta tingkat kecerdasannya (Bernardo L. Horta, Pelotas, Pelotas, 2013). Makadari itu kampanye, konseling dan informasi terkait pemberian ASI secara eksklusif dan berkelanjutan sampai umur dua tahun menjadi tanggungjawab lintas sektoral tidak hanya petugas kesehatan tetapi juga pemerintah, keluarga dan lingkungan sekitar.

\section{KESIMPULAN}

Durasi pemberian ASI Eksklusif berpengaruh terhadap tingkat mordibitas pada bayi. Durasi pemberian ASI kurang dari enam bulan terbukti 14.6 kali meningkatkan mordibitas pada bayi dibandingkan pemberian ASI lebih dari enam bulan. Selain itu karakteristik sosial yaitu dengan ibu yang bekerja lebih dari enam jam sehari 1.5 kali meningkatkan mordibitas pada bayinya.

\section{SARAN}

Konseling terhadap pekerja wanita yang menyusui harus direalisasikan dengan memberikan ruang dan fasilitas yang dapat mendukung pemberian ASI Eksklusif sehingga dapat menurunkan kejadian mordibitas pada bayi. Informasi mengenai ASI perah dan cara menyimpan 
ASI juga perlu disosialisasikan dengan baik.

\section{DAFTAR PUSTAKA}

Afifah, D. N. (2007). Faktor Yang Berperan Dalam Kegagalan Praktik Pemberian Asi Eksklusif (Studi Kualitatif di Kecamatan Tembalang, Kota Semarang Tahun 2007).

Arora, A., Manohar, N., Hayen, A., Bhole, S., Eastwood, J., Levy, S., \& Scott, J. A. (2017). Determinants of breastfeeding initiation among mothers in Sydney, Australia: findings from a birth cohort study. International Breastfeeding Journal, 12(1), 39. https://doi.org/10.1186/s13006017-0130-0

Asmarani Dian Pratiwi, Shendyca Zilma Nurzafani, Hasniah Bombang, N. I. N. (2018). Hubungan Lama Pemberian ASI dengan Status Gizi dan TUmbuh Kembang Pda Bayi Usia 6-12 bulan di Puskesmas Wajo Kota Baubau. Jurnal IImiah Praktisi Kesehatan Masyarakat Sulawesi Tenggara, 3(1).

Babakazo, P., Donnen, P., Akilimali, P., Mapatano, N., Ali, M., \& Okitolonda, E. (2015). Predictors of discontinuing exclusive breastfeeding before six months among mothers in Kinshasa : a prospective study. International Breastfeeding Journal, 1-9. https://doi.org/10.1186/s13006-015-0044-7

Badan, \& Berencana Kependudukan Nasional. (2013). Survei Demografi dan Kesehatan Indonesia.

Bernardo L. Horta, Pelotas, Pelotas, B. C. G. V. (2013). Long-term effects of breastfeeding. WHO.

Buleleng, D. K. K. (2014). Profil Kesehatan Kabupaten Buleleng Tahun 2014.

Depkes RI. (2010). Riset Kesehatan Dasar ( Riskesdas ) Tahun 2010.

Dinas Kesehatan Kabupaten Buleleng. (2015). Profil Kesehatan Kabupaten Buleleng Tahun 2015. Singaraja.

Emma, S., Jatmika, D., Shaluhiyah, Z., \& Suryoputro, A. (2014). Dukungan Tenaga Kesehatan Untuk Meningkatkan Niat lbu Hamil Dalam Memberikan ASI Eksklusif di Wilayah Kerja Puskesmas Gondokusuman , Kota Yogyakarta, 9(2).

Fatmawati, S., Rosidi, A., \& Handarsari, E. (2010). Perbedaan Pemberian Air Susu lbu Eksklusif dan Susu Formula Terhadap Kejadian Konstipasi Pada Bayi Usia 6 - 12 Bulan di Wilayah Kerja Puskesmas Kedungmundu Kota Semarang, 35-43.
FK-UGM, P. M. P. K. (PMPK). (2013). Indonesia Gagal Mencapai MDG 4 dan 5_ What next. Retrieved from https://mutupelayanankesehatan.net/22editorial/369-indonesia-gagal-mencapaimdg-4-dan-5-what-next

Fraser, D. (2011). Buku Ajar Bidan (I). Jakarta: ECG.

Gadhavi, R. N., Vidhani, M., Patel, F., Patel, A., Mehta, S., \& Chavan, L. B. (2013). Original Article Are Today' $S$ Mother Aware Enough About Breast Feeding ?: a Knowledge, Attitude and Practice Study on Urban Mothers. National Journal of Medical Research, 3(4), 396-398.

Global, W. H. O., Bank, D., Feeding, Y. C., Children, T., \& Children, U. (2007). Date updated: 2009-07-21, 2-6.

Haghighi, M., \& Abbasi, R. (2015). The Relationship between Emotional Intelligence ( $\mathrm{EI}$ ) and Breastfeeding Success in Lactating Mothers, 3(15), 15-21.

Kemenkes. (2013). PEKAN ASI SEDUNIA 2013 Kementerian Kesehatan Republik Indonesia.

Khasawneh, W., \& Khasawneh, A. A. (2017). Predictors and barriers to breastfeeding in north of Jordan: could we do better? International Breastfeeding Journal, 12(1), 49. https://doi.org/10.1186/s13006-0170140-y

Lee, S. Y., \& Jang, G. J. (2016). Prevalence and Predictors of Exclusive Breastfeeding in Late Preterm Infants at, 22(2), 79-86.

Made Kurnia Widiastuti Giri, Nunuk Suryani, P. M. K. (2013). Hubungan Pengetahuan Dan Sikap Ibu Tentang Pemberian Asi Serta Pemberian Asi Eksklusif Dengan Status Gizi Balita Usia 6-24 Bulan ( Di Kelurahan Kampung Kajanan Kecamatan Buleleng), 1(1), 24-37.

Nurmiati, B. (2008). Pengaruh durasi pemberian ASI terhadap ketahanan hidup bayi di indonesia. Makara Kesehatan, 12(2), 4752.

Putu Dian Prima Kusuma Dewi, P. S. M. (2016). Barriers And Implementation Of Early Breastfeeding Initiation In Midwife's Practice, Buleleng Regency Bali. Proceedings International Seminar "Midwifery Education Reform," I.

RI, P. K. (2014). Situasi dan Analisis ASI Eksklusif.

Saleh, L. O. A. (2011). Faktor-Faktor Yang Menghambat Praktik Asi Eksklusif Pada Bayi Usia 0-6 Bulan. 
Shifraw, T., Worku, A., \& Berhane, Y. (2015). Factors associated exclusive breastfeeding practices of urban women in Addis Ababa public health centers, Ethiopia: a cross sectional study. International Breastfeeding Journal, $\quad 10(1)$, 22. https://doi.org/10.1186/s13006-015-0047-4

Suresh, S., Sharma, K. K., Saksena, M., Thukral, A., Agarwal, R., \& Vatsa, M. (2014). Predictors of Breastfeeding Problems in The First Postnatal Week and Its Effect on Exclusive Breastfeeding Rate at Six Months: Experience in A Tertiary Care Centre in Northern India, 58(4), 58-61. https://doi.org/10.4103/0019-557X.146292

Takahashi, K., Ganchimeg, T., Ota, E., \& Vogel, J. P. (2017). Prevalence of early initiation of breastfeeding and determinants of delayed initiation of breastfeeding: secondary analysis of the WHO Global Survey. Nature Publishing Group, (February), 110. https://doi.org/10.1038/srep44868

Tilahun, G., Degu, G., Azale, T., \& Tigabu, A. (2016). Prevalence and associated factors of timely initiation of breastfeeding among mothers at Debre Berhan town, Ethiopia: a cross- sectional study, 1-9. https://doi.org/10.1186/s13006-016-0086-5

WHO. (2012). WHA Global Nutrition Targets 2025 : Breastfeeding Policy Brief.

WHO. (2016). BREASTFEEDING THE GOAL.

Yuliasih, L. K. (2016). Laporan Tahunan Program Gizi Puskesmas Sawan I. 